\title{
The Possibility of Reducing Individual Motorised Traffic through the Location of Collection Points Using the Example of Gdańsk, Poland
}

\author{
Grazyna Chaberek $\mathbb{1}$
}

check for

updates

Citation: Chaberek, G. The Possibility of Reducing Individual Motorised Traffic through the Location of Collection Points Using the Example of Gdańsk, Poland. Sustainability 2021, 13, 10661. https://doi.org/10.3390/ su131910661

Academic Editors: Stefano Carrese and Sergio Maria Patella

Received: 17 July 2021

Accepted: 23 September 2021

Published: 25 September 2021

Publisher's Note: MDPI stays neutral with regard to jurisdictional claims in published maps and institutional affiliations.

Copyright: (C) 2021 by the author. Licensee MDPI, Basel, Switzerland. This article is an open access article distributed under the terms and conditions of the Creative Commons Attribution (CC BY) license (https:/ / creativecommons.org/licenses/by/ $4.0 /)$.
Division of Spatial Management, Faculty of Social Science, Institute of Socio-Economic Geography and Spatial Management, University of Gdansk, 80-309 Gdańsk, Poland; grazyna.chaberek@ug.edu.pl

\begin{abstract}
Problems in urban areas at present are caused by the high traffic volumes of motor vehicles. Changing commercial behaviour into e-commerce reduces the need for individual customers to visit shopping centres and increases the need for freight transport to geographically dispersed consumers. In this case, one solution to reduce the number of lorry journeys may be collection points, such as a network of parcel lockers. However, the use of collection points has only a limited impact on reducing the number of cars on the streets because half of the journeys to parcel lockers are still made by car. This study assumes that consumers' choice of how to collect their parcels depends on the available infrastructure and the time needed to reach the pick-up point, which depends on the distance from the place of residence/work/school. The purpose of this research was to analyse the location of collection points in relation to the alternative infrastructure and places of residence/work/school using Gdańsk, Poland, as an example. The analysis showed that collection points are usually easily accessible by car, are not always accessible by foot, and in only a few cases are easily accessible by bicycle.
\end{abstract}

Keywords: city logistics; last mile; collecting point delivery; parcel lockers; urban sustainable development; systemic approach

\section{Introduction}

One of the main obstacles to the sustainable development of urban areas around the world is the dense traffic of passenger cars and vans in cities, which causes excessive greenhouse gas emissions, vibration, noise, and dangerous situations, especially for pedestrians and cyclists. Other aggravating factors are the heavy dependence on passenger cars for covering even small distances and the persistently high motorisation rate [1,2].

Additionally, as e-commerce develops, the proportion of delivery vehicles on urban streets increases, which generates additional traffic throughout the day, not only at rush hour. Many studies have discussed the problem of the impact of e-commerce and new solutions for last-mile distribution on the environment and sustainable urban development [3-6]. Last-mile distribution related to e-commerce is complicated and costly $[7,8]$. Some research on e-commerce has studied solutions aiming to improve, economise, and optimise service from the point of view of both companies in the supply chain and end consumers [9]. One of the main points of interest for researchers is deliveries to retail collection points $[10,11]$. Networks of retail collection points are now being rolled out rapidly in many countries in order to increase consumer convenience and reduce delivery costs [12]. The European Commission has also drawn attention to the problem of e-commerce and its impact on sustainable urban development, noting the pro-ecological opportunities in modern solutions for optimising last-mile logistics, including the development of retail collection points [13].

Solutions aimed at reducing the undesirable consequences of high motorisation rates in cities may take two directions: 
1. Those leading to changes in the method of mobility with the same number of journeys (public transport, cycling, and walking);

2. Those leading to a reduction in the number of journeys (like Internet of Things, e-documents, and other virtual products and services) or integrating two or more journeys into one.

The research presented in this article was based on the assumption that individual motorisation and motor traffic caused by the supply of goods and services are to some extent interchangeable. Figure 1 presents a diagram of the assumption of the interchangeability of car traffic needs in cities.

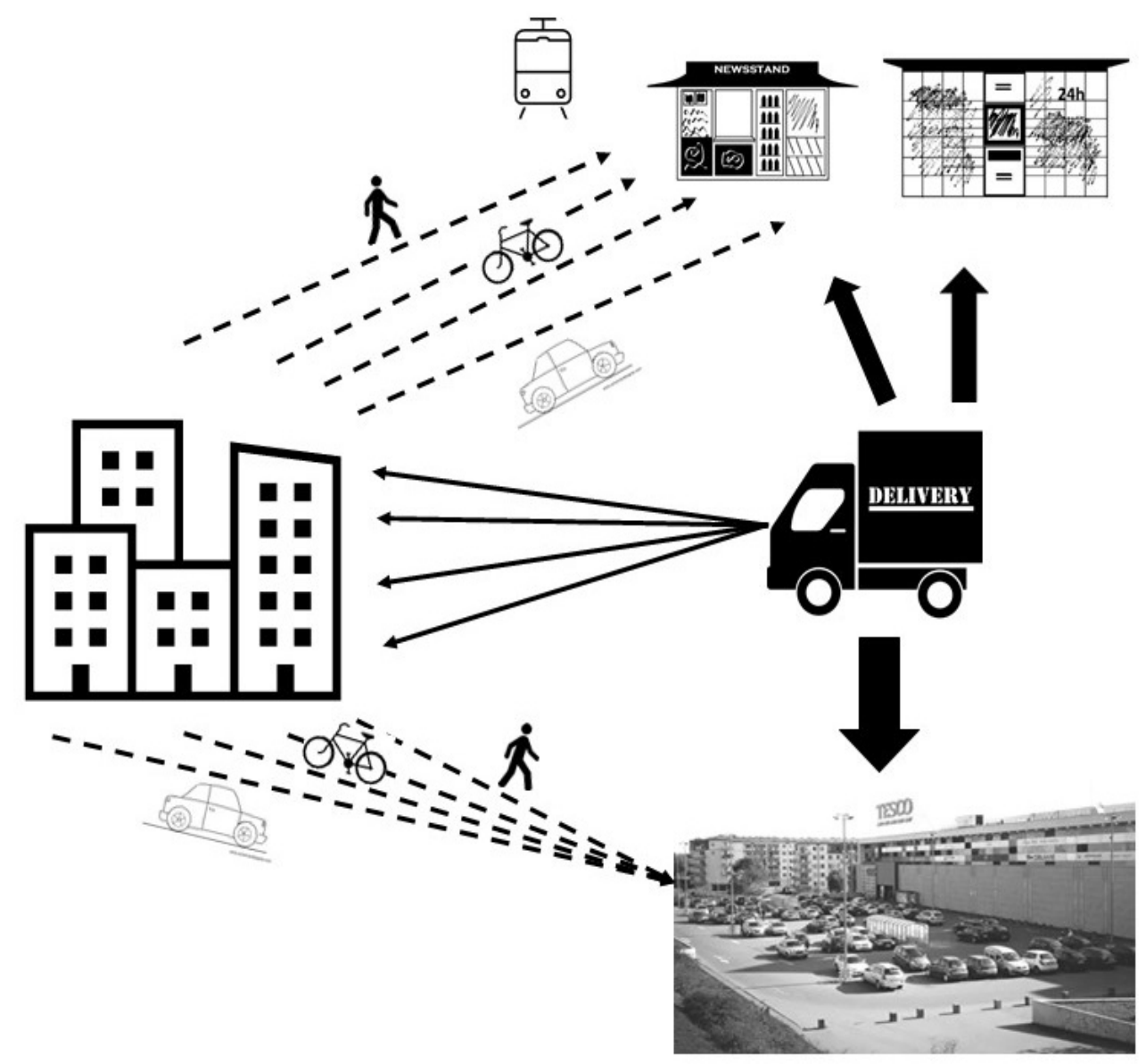

Figure 1. Interchangeability of car traffic and alternative travel methods.

The traditional way to connect customers with commercial goods is to sell them in large shopping centres where customers can buy everything in one place. Such deliveries require the movement of larger vehicles with a certain frequency. Subsequently, each consumer has to find the goods themselves. If customers go to the market by car, this type of distribution favours the generation of individual motor traffic. As a result of the growth of e-commerce, the demand for home/office deliveries has vastly increased. Door-to-door deliveries in fact reduce the need for individual journeys to points of sale, but they generate more traffic from delivery vans travelling to reach far-flung end-customers.

Scattered destinations can be reduced to some extent by introducing collective parcel collection points. The following types of retail collection points can be used [12]:

- Parcel lockers: these banks of secure lockers are generally found in places that are accessible from early until late in the day and can provide an adequate level of security, such as railway stations, supermarket car parks, and petrol station forecourts.

- Parcel shops: staffed outlets, most commonly convenience stores, newsstands, or other shops with long hours, including florists, petrol stations, and other outlets. 
Research in this field treats parcel lockers as an important link in the entire system of heterogeneous delivery methods for handling deliveries due to e-commerce [14].

In Poland, parcel lockers are an extremely popular solution for deliveries of online shopping. These are a solution that is becoming more and more popular among online customers every year. This is due to the greater flexibility offered by picking up packages after working hours [15]. Until recently, parcel lockers were second to online shopping delivery (with home delivery by courier following); since 2020, they have taken the top spot [16], and as a result of the social distancing recommended to protect against COVID-19 infection, parcel lockers have become the first choice for most online purchases. Deliveries to parcel lockers have become a very good alternative to purchases requiring contact between the carrier and the customer, and not only in Poland. For example, Koloni launched a smart locker that can reduce COVID-19 contagion by eliminating human contact during deliveries of parcels and food [17].

Delivery to parcel lockers has gained popularity due to the independence and flexibility the customer has in picking up their package and the greater choice of collection points offered [18]. Additionally, in October 2016 a new service of collection points was introduced in a chain of popular convenience stores in Poland.

Such distribution solutions generate lower costs for the supplier. Delivery is faster [8] and may to some extent reduce the number of vans on the streets or the length of their trips, as various studies have shown $[19,20]$. However, this type of delivery requires the consumer to be involved in the process of obtaining their goods. If the end customer carries out their part of the logistics process by car, this solution will not reduce car traffic in the city [21]. Such a solution could potentially have a positive impact on urban sustainability if consumers travelled some other way to obtain their package than by car or if they always combined the collection of packages with their other journeys (for example, commuting to/from work). Another solution indicated in the research is using cargo bikes for the final stage of delivery [22].

The general thesis that parcel lockers are able to reduce the number of cars on the streets, provided that consumers collect their parcels whilst on other journeys or that they reach the collection point through some other means than by car, was also a contribution to research conducted by a team from the Maritime University of Szczecin, Poland [18]. However, the study conducted in Szczecin found that most consumers reached parcel lockers by car.

With such results from the existing research, the next question is how to change customers' behaviour and how to encourage them to travel to collection points without using a car. The basic hypothesis is that the layout and infrastructure of cities determine the mobility of its residents. This hypothesis is based on the idea that the city is a system and that the behaviours (processes) exhibited in the system are conditioned by the structure of the system. This systemic perspective dictates that a system's structure shapes individual actions and creates the conditions enabling particular types of behaviour [23]. The structure of cities as a decisive factor in the mobile behaviour of residents has been the subject of many studies. The influence of a city's structure on mobile behaviour, which determines the emission of greenhouse gasses, has also been investigated, including through looking for relationships between a city's structure and the effects of greenhouse gas emissions [24,25]. Research is also being conducted at the level of the impact of infrastructure on behaviour, including mobile behaviour. Other urban studies have also focused on this idea [26-29]. As quoted by Montgomery, Jan Gehl stated that he and his team have discovered that if road space increased, the number of cars on the road would increase too. Thus, if there were more bicycle lanes, more bicycles would be ridden around the city, and if more space was made for people, more people would take to the streets, which of course would lead to the emergence of public life [28]. 'When we look at the history of cities, we can clearly see that urban design and structures have an impact on people's behaviour and the way cities operate' [27]. 
With this assumption, it can be postulated that in order to induce pro-ecological behaviour among residents-which would consist of limiting the use of personal cars in urban spaces-attention should be paid to the location of collection points (parcel lockers), including the infrastructure available at all facilities that require the mobility of residents. With these assumptions in mind, we undertook research on the location of parcel lockers and other collective collection points (newsstands and convenience stores) in relation to roads and alternative types of infrastructure (cycling and walking lanes).

The following sections of the article discuss the questions and research hypotheses, the research processes carried out, and the methods used. The results of the survey and GIS analysis are then presented. The article concludes with a discussion of how the results can be useful to stakeholders who can, through their decisions, influence sustainable urban development.

\section{Materials and Methods}

A flowchart of the study is presented to better illustrate the individual stages of the study (Figure 2).

\section{Statistic analysis}

Collecting and analyzing the the preferences of customers in Gdańsk as to parcel collecting

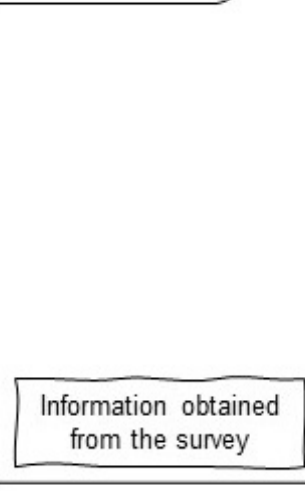
responses to the survey regarding

\section{Spatial analysis GIS}

1. Inventory of pick-up points in the city area

2. Preparation of data layers for the analysis:

- Pick-up points layer

- City boundary and district boundaries with an assigned population size layer

- A layer of cover with urban tissue (corine)

- Layer of roads

- Layer of roads with permitted bicycle traffic
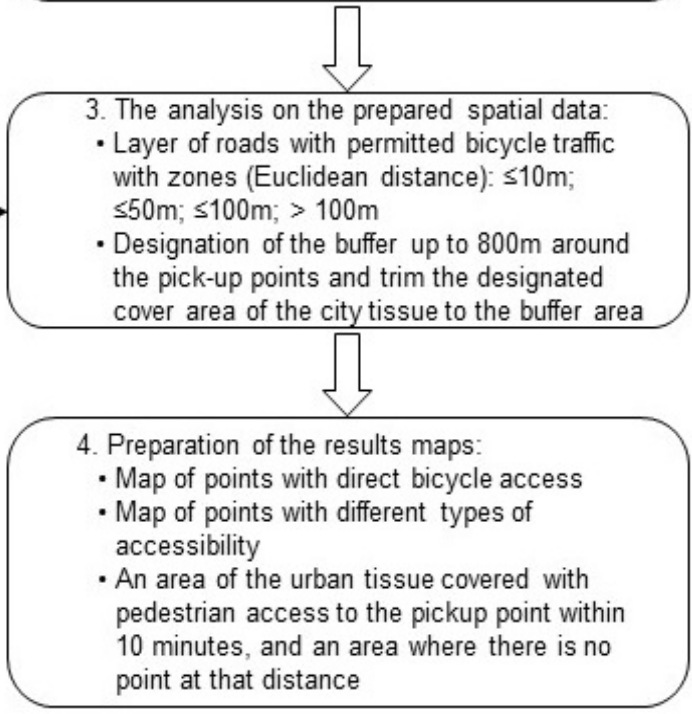

Figure 2. Stages of the analysis.

Due to the fact that the study was intended to cover one city, the first step was to examine to what extent the behaviour of e-commerce customers in choosing a method for collecting parcels was consistent with the findings of the cited studies for the whole of Poland $[15,18]$. For this purpose, a small pilot study was conducted on an available sample of academic teachers and students from the University of Gdańsk (UG). The survey was aimed only at people who declared that they shop online. As e-commerce reports 
show that the main group of people buying online are those with a higher education [30], studying a group of university employees and students was justified.

The survey was in the form of an online questionnaire that was sent to email addresses from a database of 600 employees' addresses from UG research units. The link to the questionnaire was also placed on the UG fan page. A total of 169 returned questionnaires were received. The questionnaire pertained to behaviours related to the choice of delivery mode when shopping online and of collection when a delivery other than direct home/office was chosen. The main questions asked were as follows:

- How do the respondents reach the collection point (by car, bicycle, on foot)?

- Do they combine parcel collection with other reasons for travel (to/from work, shopping, or recreation)?

- How far would they be willing to go to a collection point to retrieve a parcel (distance expressed in time: up to $5 \mathrm{~min}$, up to $10 \mathrm{~min}$, up to $20 \mathrm{~min}$, or over $20 \mathrm{~min}$ )?

The subsequent analysis of the location of collection points was aimed at investigating whether the location of parcel lockers in relation to the transport infrastructure is such that it could support alternative methods of travelling to parcel lockers. Therefore, the detailed research questions concerned the location of the parcel collection points in relation to road, bicycle, and pedestrian infrastructure. The following research questions were formulated:

- What proportion of collection points is directly accessible by car?

- What proportion of collection points is directly accessible for the bicycle infrastructure?

- What proportion of collection points has direct access to public transport stops?

- What proportion of collection points has direct access to pedestrian infrastructure?

- What level of accessibility is there for walking to collection points in the urban tissue (residential, commercial, and industrial areas)?

The analysis was carried out with the use of GIS software tools. To prepare a map layer with collection points, a field inventory was carried out using the collector application, attributing the appropriate characteristics to each point. The analysis was limited to the administrative borders of the city of Gdańsk (Figure 3). The database of addresses of collection points in Gdańsk was obtained from the websites of the operators (InPost for parcel lockers, Paczka w RUCHU by the Polish Post for newsstands, and Żabka for convenience stores).

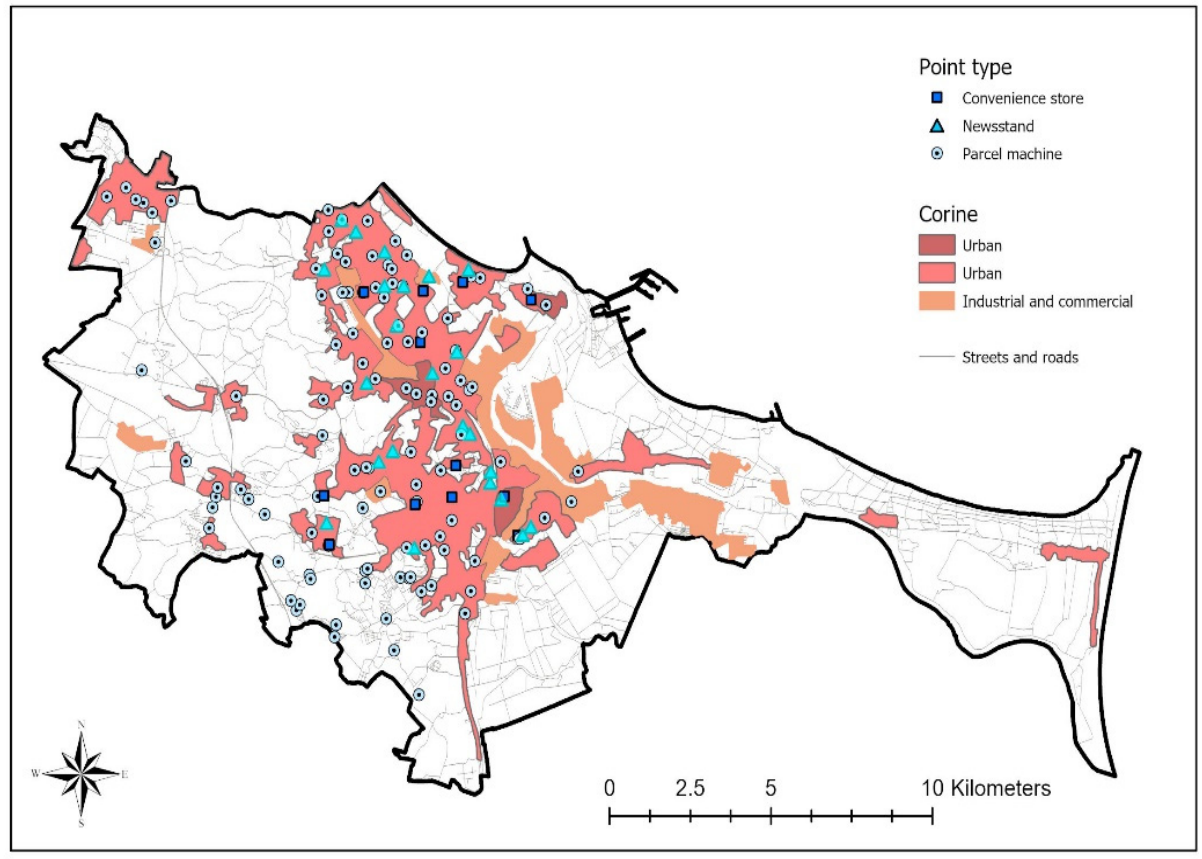

Figure 3. Collection points shown with an urban tissue map. 
The following indicators were used to study the availability of the collection points from particular types of infrastructure (Table 1):

Table 1. Indicators describing the characteristics of collection points.

\begin{tabular}{|c|c|c|}
\hline Characteristic & Description & Indicator \\
\hline & & Parcel locker \\
\hline Type of collection point & Type of collection point & Newsstand \\
\hline & & $\begin{array}{l}\text { Convenience store } \\
\text { 1-Parking space }\end{array}$ \\
\hline Car accessibility & $\begin{array}{l}\text { Infrastructure that enables legal and safe } \\
\text { stopping directly at the collection point at the } \\
\text { time of parcel collection }\end{array}$ & $\begin{array}{l}\text { 2-Parking space up to } 50 \mathrm{~m} \text { away } \\
\text { 3-Permission to stop }{ }^{1} \\
\text { 4-Permission to stop up to } 50 \mathrm{~m} \\
\text { away }\end{array}$ \\
\hline & & $5-\mathrm{No}=0$ \\
\hline Bicycle accessibility & $\begin{array}{l}\text { Infrastructure that enables legal and safe } \\
\text { access to the parcel collection point by bicycle }\end{array}$ & $\begin{array}{l}\text { 1-Bicycle paths } \\
\text { 2-Roads with permission for bicycle } \\
\text { traffic }\end{array}$ \\
\hline Public transport accessibility & $\begin{array}{l}\text { A public transport stop (bus or tram) in the } \\
\text { immediate vicinity of the collection point }\end{array}$ & $\begin{array}{c}\text { 3-No }=0 \\
\text { 1-Public transport stop } \\
\text { 2-Public transport stop up to } 50 \mathrm{~m} \\
\text { away } \\
\text { 3-No }=0 \\
\text { 1-Pavement }\end{array}$ \\
\hline Walking accessibility & $\begin{array}{l}\text { Nearby infrastructure that allows legal and } \\
\text { safe access to the collection point on foot, } \\
\text { using a pavement or other road with } \\
\text { pedestrian traffic permitted }\end{array}$ & $\begin{array}{l}\text { 2-No }=0 \\
\text { 3-Residential, commercial, and } \\
\text { industrial areas of the city covered } \\
\text { with collection points with a buffer of } \\
800 \mathrm{~m}\end{array}$ \\
\hline $\begin{array}{l}\text { Possibility of combining parcel collection } \\
\text { with other reasons for traveling }\end{array}$ & $\begin{array}{l}\text { Strong presence of other commercial services } \\
\text { or educational or office functions at the } \\
\text { collection point }\end{array}$ & $1-\mathrm{Yes} / \mathrm{No}=1 / 0$ \\
\hline
\end{tabular}

${ }^{1}$ The time allowed to stop is indicated by a road sign and is usually $5-15 \mathrm{~min}$.

Car accessibility was determined by the possibility of legally stopping the car directly at the parcel locker long enough for the parcel to be picked up. Walking accessibility was expressed by the possibility of reaching the collection point safely and legally on foot. Therefore, we checked in the field whether a pavement was connected with other pedestrian routes leading to the parcel locker. In order to determine bicycle accessibility, a map of bicycle routes and paths which allowed bicycle traffic from the website of the city of Gdańsk was used; four zones (Euclidean distance) were then designated from the roads allowing bicycle traffic: up to $10 \mathrm{~m}$, up to $50 \mathrm{~m}$, up to $100 \mathrm{~m}$, and areas over $100 \mathrm{~m}$ (Figure 4).

Of course, pedestrians are physically able to go anywhere, even where there is no pavement. However, there may be barriers and pedestrians may feel insecure. Although pedestrians in Polish cities are accustomed to constantly overcoming infrastructural barriers, as mentioned in the introduction, a condition for the sustainable development of cities is spaces that are generally favourable to pedestrian and bicycle traffic. Cyclists are also able to reach many places - even without the appropriate infrastructure - as they can also physically move around streets and pavements. However, in this study we only considered access to collection points that was fully in compliance with the traffic code so as not to exacerbate spatial conflicts. Moving by bicycle leads to conflicts between cyclists and pedestrians and between cyclists and drivers. This conflict mainly occurs over space on the streets, which is particularly visible in Poland [31]. 


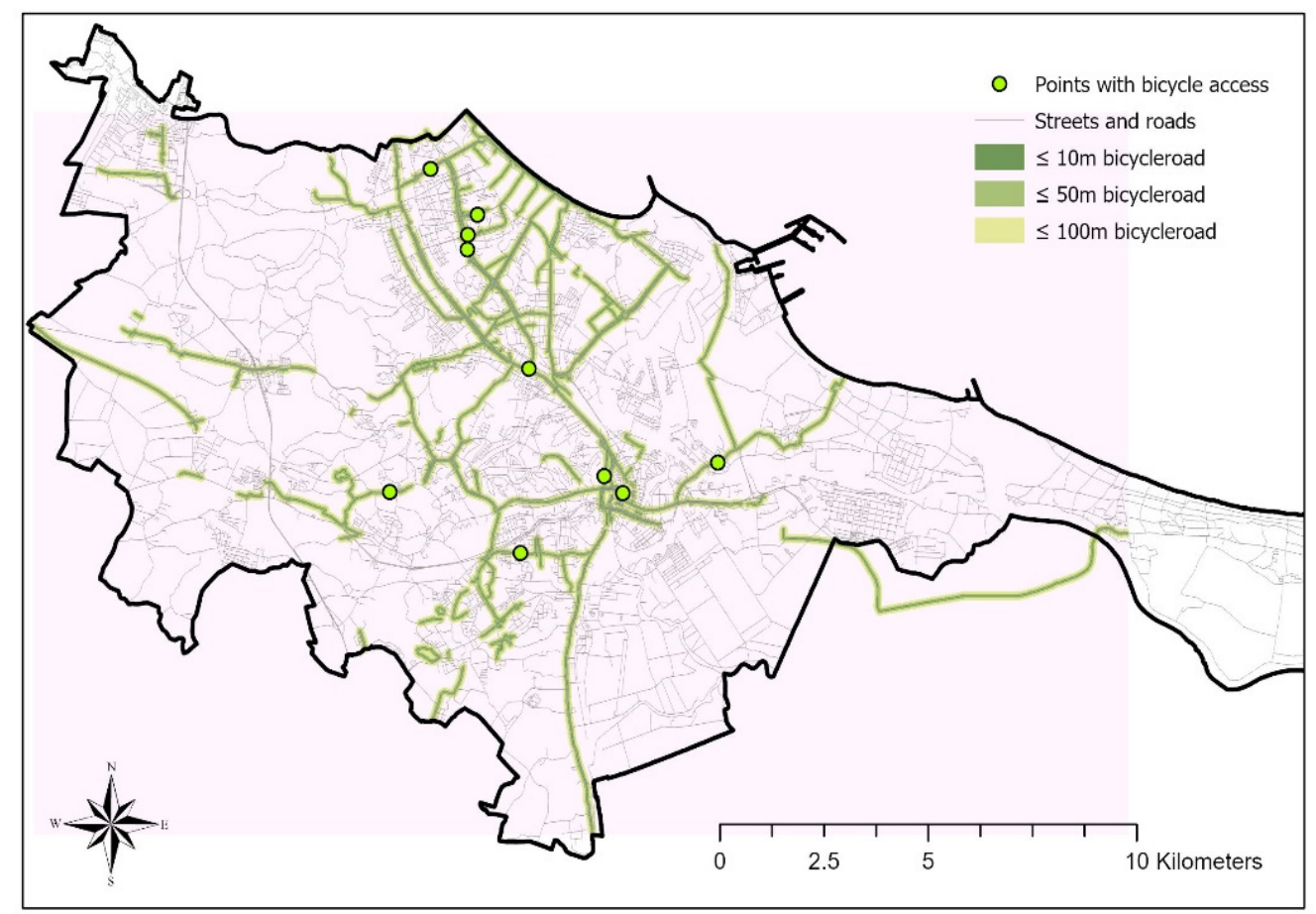

Figure 4. Streets allowing bicycles and zones representing distances of up to $10 \mathrm{~m}$, up to $50 \mathrm{~m}$, and up to $100 \mathrm{~m}$, as well as pick-up points with direct bicycle infrastructure access.

Next, the area of urban tissue (residential, commercial, and industrial) with pedestrian accessibility within $800 \mathrm{~m}$ of a collection point was delimited. This defined the area not covered by pedestrian access at the most acceptable distance).

\section{Results}

Due to the survey results being similar to those of other studies [32], it can be concluded that the results and the conclusions we drew based on them are correct. This survey revealed that consumers in Gdańsk very often choose a parcel locker or a newsstand as their preferred method of delivery for their online purchases. This means that the parcel does not reach the consumer directly; thus, consumers have to move towards the parcel to pick it up. It is therefore important to consider how consumers travel to accomplish this. Table 2 contains the most important results from the survey.

Table 2. Most frequently chosen (always or almost always) means of collecting a parcel, divided into parcel lockers and newsstands.

\begin{tabular}{ccc}
\hline Method of Access & Parcel Locker & Newsstand \\
\hline On foot & $47 \%$ & $41 \%$ \\
By car & $46 \%$ & $22 \%$ \\
By bicycle & $12 \%$ & $7 \%$ \\
\hline
\end{tabular}

The survey showed that among the methods of delivery chosen for online shopping, the most popular choice is courier delivery-almost $80 \%$ of the respondents chose courier delivery to their door. The difference is minor, as over $79 \%$ of the respondents chose delivery to a parcel locker. Newsstands were the third most frequently chosen. Only one of the respondents indicated convenience stores as a collection point, so this type was omitted in the discussion of the results.

The survey showed that $47 \%$ of the respondents who chose to use a parcel locker usually walk there (always or almost always), but again the results are similar: more than $46 \%$ of them usually get there by car, and among the respondents who collect parcels at a 
newsstand, $41 \%$ declared walking to pick up a parcel and $22 \%$ typically travelled to the newsstand by car. Nearly half $(47 \%)$ of the respondents stated that car accessibility to the collection point was important or very important for them. Reaching a parcel locker by bicycle was selected by nearly $12 \%$ of the respondents, while cycling to a newsstand was selected by $7 \%$.

Nearly half (29\%) of those questioned declared that they travel solely to pick up parcels, whilst others pick up parcels during other trips-mainly to/from work or school or for shopping or recreation (e.g., walking a dog). The pilot study, as well as other studies, found that e-commerce using collective collection points generates additional trips around the city and that half of these trips are made by car.

The second part of the study-i.e., the spatial data analysis-made it possible to measure the extent to which the location of collection points encourages people to travel by car and to what extent it can encourage or discourage people from choosing alternative travel methods. Figure 5 shows a map of the collection points and the accessibility to various types of infrastructure.

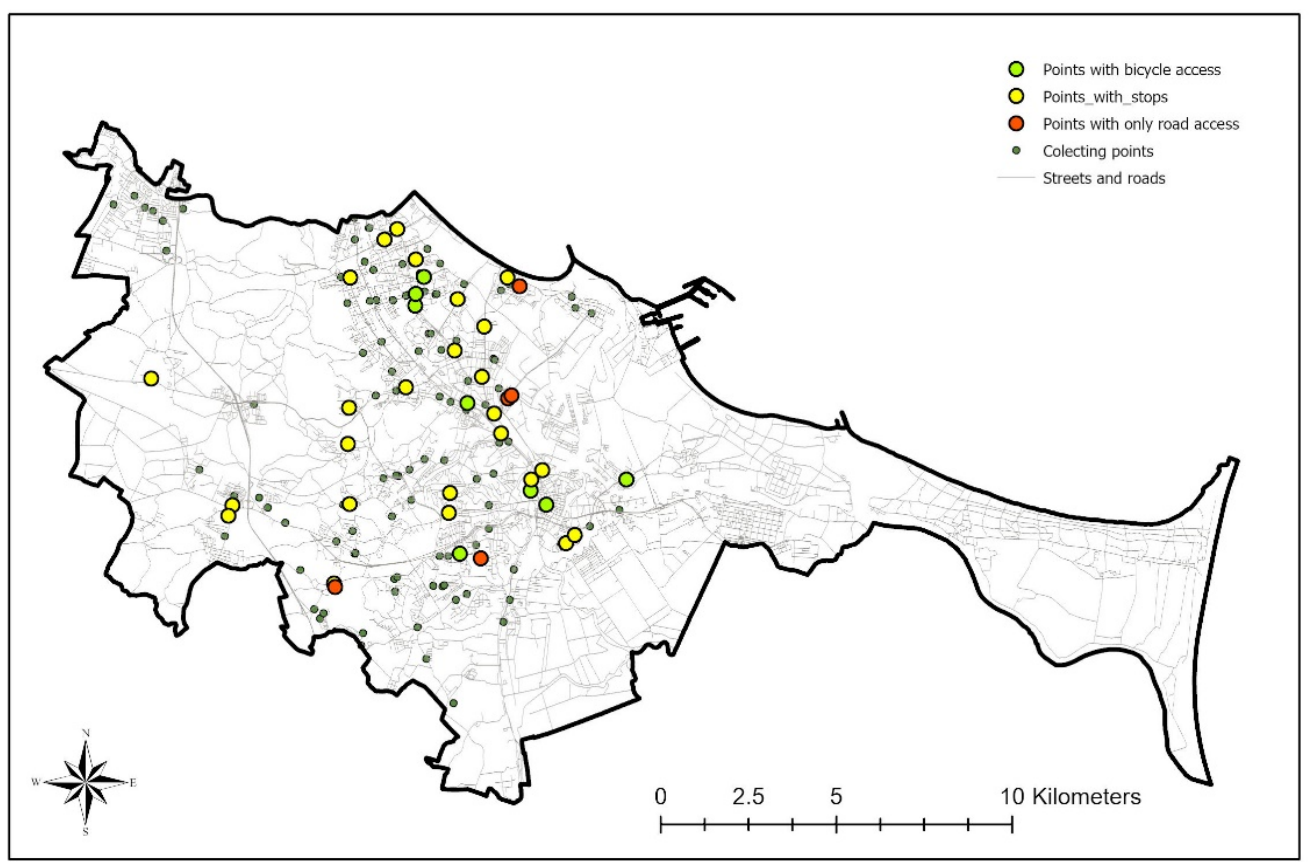

Figure 5. Parcel collection points in Gdańsk according to dominant type of accessibility.

In Figure 5, the collection points with direct access to bicycle infrastructure are marked in green. Yellow indicates the points that are directly accessible by public transport (located at public transport stops). Points that are accessible only by car are marked in red (not even pedestrian routes, such as a pavement, are nearby).

In addition, the survey established that $23 \%$ of the respondents were willing to travel only a maximum of $5 \mathrm{~min}$ for a parcel. More than half of the respondents were willing to travel $10 \mathrm{~min}$ for a parcel (56\%) and $21 \%$ even further. It was assumed in the study that $10 \mathrm{~min}$ of walking is about $800 \mathrm{~m}$. As shown in Figure 6, most of the area of residential, commercial, and industrial tissue is covered by a network of parcel collection points within a $10 \mathrm{~min}$ walk $(800 \mathrm{~m})$. However, $22 \%$ of the area most used by residents does not have access to a collection point within walking distance. 


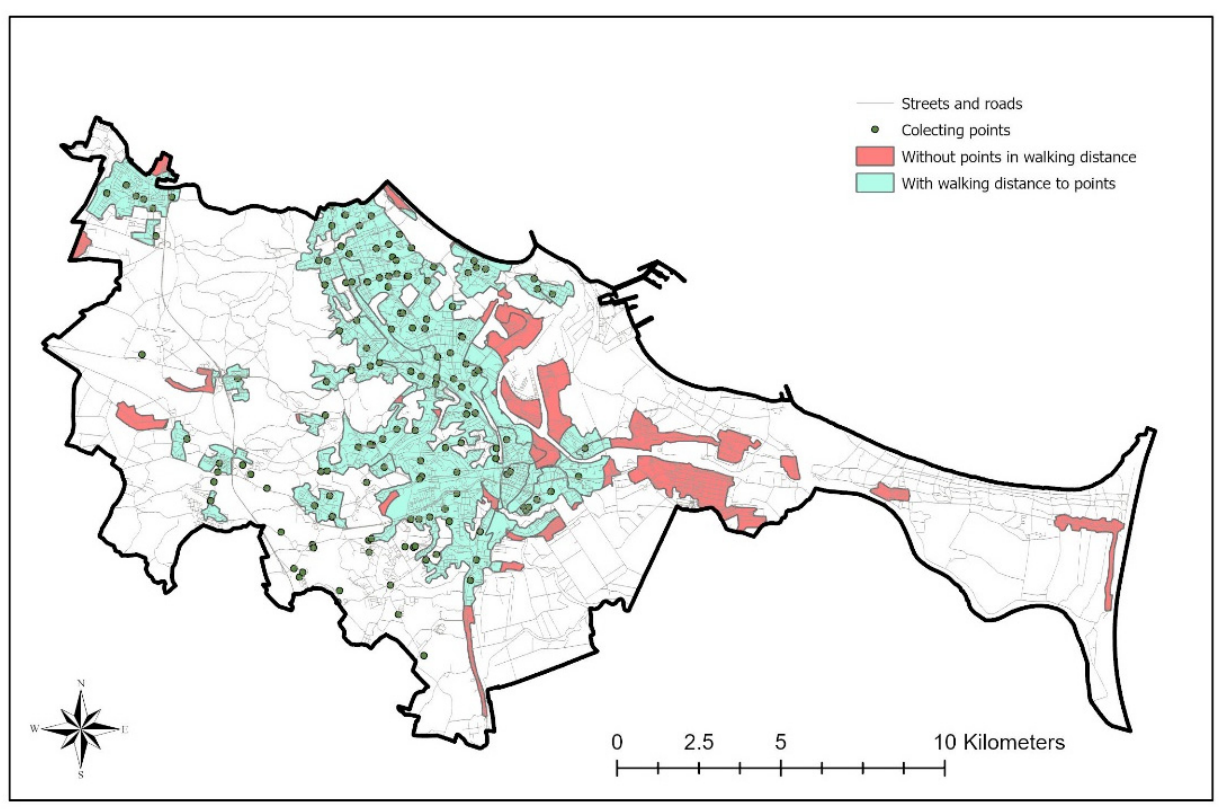

Figure 6. The cover of urban tissue with collection points within $800 \mathrm{~m}$.

In summary, the spatial analysis revealed the following points.

- The vast majority of parcel collection points are very easily accessible by car, which certainly encourages customers to travel by car to collect parcels.

- A large number of parcel machines are located in places intended only for vehicle users (car washes or petrol stations).

- The lack of adequate cycling infrastructure at the vast majority of collection points may to some extent discourage people from cycling to pick up a parcel.

- Newsstands are located along pedestrian routes more often than parcel lockers, which are also very often used for cycling; despite this, most newsstands are also easily accessible by car.

- Newsstands are located at tram and bus stops more often than parcel lockers.

- The vast majority of journeys to collect a parcel can be combined with ones for other purposes, such as commuting to/from work/school and shopping.

- Potentially all collection points are within walking distance (10 min or $800 \mathrm{~m})$ of residential, commercial, and industrial areas.

\section{Discussion and Conclusions}

Many studies have focussed on the location of collection points in places where consumers are concentrated [33]. Thus, the collection point locations 'follow' the potential user. Lachapelle et al. indicated that parcel lockers should be available primarily to vehicle users. Collection points should have close, convenient, and bountiful parking nearby; be close to higher-level road infrastructure; and should more frequently be located at petrol stations or shopping centres, where collecting a parcel may be combined with other purposes [34]. A previous study on this topic was conducted in car-dominant Australian cities. This article proposes the reverse of this view-i.e., enabling users to change their behaviour by creating favourable accessibility to alternative infrastructure.

The location of the collection points is based on an arm's length and according to local land lending legislation. If cities' authorities have an integrated, multi-faceted policy of restricting motorisation; use more tools than simply 'no traffic' signs; and create restricted parking zones, private companies could be involved in promoting such city policies. More and more companies are willing to act to encourage sustainable development. One such action could be to pay attention to the location of collection points-not only in terms of serving as many potential customers as possible in a given location, but also in terms of 
the availability of alternative infrastructure. In fact, parcel lockers are clearly located in a convenient way for vehicle users. Very often there is a car park right next to the parcel locker and no pavement.

The issue of location changes the perspective somewhat towards pilot research on mobile lockers. Parcel lockers that can be moved during the day depending on demand can also be moved in relation to the infrastructure. Ultimately, however, location is always a physical presence at some point in space. In cities where free space is limited and space on the streets is valuable and intended for many users, it is not always possible to find available space [35]. It is most likely that special spaces will have to be created to will allow mobile lockers to be parked at certain times. The locations of such parking zones for mobile lockers should be determined in the light of the availability of means of transport other than cars.

The presented study is the starting point for further analyses. Determining the conditions in which pedestrians can walk is very important in order to include customer's foot mobility in handling e-commerce deliveries. The $10 \mathrm{~min}$-i.e., $800 \mathrm{~m}$-distance used in this study, which was accepted by the largest group of respondents, is very sensitive to the remaining personal and external conditions of walking, including infrastructure. Infrastructural conditions and barriers can have a huge impact on people's willingness to travel on foot. Apart from factors independent of the infrastructure, such as weather, physical condition, or other personal aspects, pedestrians may encounter obstacles that make it difficult to reach the parcel locker by walking or even discourage them. These factors include the slope of the land; accessibility to pedestrian infrastructure along the entire route; the number of intersections, including those with traffic lights; barriers in the form of other buildings or fenced spaces; and barriers in the form of high-speed roads without crossings. [36]. All of these barriers can lengthen the route or reduce a customer's feeling of safety, which can discourage pedestrian mobility. For example, the research team of $\mathrm{Xu}$ Junping et al. studied micro-level street data and their impact on pedestrian travel [37].

GIS tools allow the multi-criteria modelling of locations in real spatial conditions, because with a data layer that inventories the existing infrastructure it is easy to determine the best locations for collection points. Creating a multicriterial model in a GIS environment that would help in making location decisions for parcel lockers considering the existing physical infrastructure and space is a subject of the author's further research.

Other factors may also affect the way orders are collected from parcel lockers. Research on various scenarios of last-mile logistics organisation carried out in Turin showed that although the orders mostly arrive the day before the planning process, customers might express time delivery restrictions, requiring parcel delivery in a particular timeslot of the day. The capacities of the collecting points cannot be exceeded and all the orders must be delivered, reflecting the current practices in the market. Additional capacity can be bought on the spot market at a higher price [38]. Therefore, one delivery scenario may force consumers to pick up a parcel at a certain time in a specific place so as to avoid, for example, higher delivery costs. The time that the consumer has at their disposal may affect the method they use for collecting the parcel. In the event that the space of the parcel locker cannot be occupied for a long time, the consumer may be motivated to collect parcels at a certain period-e.g., on the way from work-because otherwise the longer presence of the parcel in the parcel locker may affect the additional cost of delivery. In this way, this can lead to reduction in urban travel dedicated to picking up parcels.

In an ideal scenario, an operator (carrier or seller) would engage in activities that support the sustainable development of the city and demonstrate this commitment with models for locating collection points not only according to the number of potential customers served or the volume of traffic at a given parcel locker but also to its accessibility to infrastructure not geared towards cars. In the minimum scenario, it is important that the operator at least takes into account the needs of users other than drivers. 
Funding: This research did not receive any specific grant from funding agencies in the public, commercial, or not-for-profit sectors.

Institutional Review Board Statement: Not applicable.

Informed Consent Statement: Not applicable.

Data Availability Statement: The data presented in this study are openly available in Most Wiedzy at https:/ / doi.org/10.34808/0vj7-nf08, accessed on 25 September 2021.

Conflicts of Interest: The authors declare no conflict of interest.

\section{References}

1. Corazza, M.V.; Guida, U.; Musso, A.; Tozzi, M. A European vision for more environmentally friendly buses. Transp. Res. Part D Transp. Environ. 2016, 45, 48-63. [CrossRef]

2. Eurostat. Energy, Transport and Environment Indicators; Publications Office of the European Union: Luxemburg, Germany, 2014; ISBN 9789279412561.

3. Cullinane, S. From bricks to clicks: The impact of online retailing on transport and the environment. Transp. Rev. 2009, 29, 759-776. [CrossRef]

4. Edwards, J.B.; McKinnon, A.C.; Cullinane, S.L. Comparative analysis of the carbon footprints of conventional and online retailing: A "last mile" perspective. Int. J. Phys. Distrib. Logist. Manag. 2010. [CrossRef]

5. Lachapelle, U.; Jean-Germain, F. Personal use of the Internet and travel: Evidence from the Canadian General Social Survey's 2010 time use module. Travel Behav. Soc. 2019, 14, 81-91. [CrossRef]

6. Cardenas, I.; Beckers, J.; Vanelslander, T.; Verhetsel, A.; Dewulf, W. Spatial characteristics of failed and successful Ecommerce deliveries in Belgian cities. In Proceedings of the 6th International Conference on Information Systems, Logistics and Supply Chain, Bordeaux, France, 1-4 June 2016; p. 10.

7. Kapetanis, G.N.; Psaraftis, H.N.; Spyrou, D. A Simple Synchro-Modal Decision Support Tool for the Piraeus Container Terminal. Transp. Res. Procedia 2016, 14, 2860-2869. [CrossRef]

8. Morganti, E.; Seidel, S.; Blanquart, C.; Dablanc, L.; Lenz, B. The Impact of E-commerce on Final Deliveries: Alternative Parcel Delivery Services in France and Germany. Transp. Res. Procedia 2014, 4, 178-190. [CrossRef]

9. Mangiaracina, R.; Perego, A.; Seghezzi, A.; Tumino, A. Innovative solutions to increase last-mile delivery efficiency in B2C e-commerce: A literature review. Int. J. Phys. Distrib. Logist. Manag. 2019, 49, 901-920. [CrossRef]

10. Yuen, K.F.; Wang, X.; Ma, F.; Wong, Y.D. The determinants of customers' intention to use smart lockers for last-mile deliveries. J. Retail. Consum. Serv. 2019, 49, 316-326. [CrossRef]

11. Deutsch, Y.; Golany, B. A parcel locker network as a solution to the logistics last mile problem. Int. J. Prod. Res. 2018, 56, 251-261. [CrossRef]

12. Apex Insight. Global Parcel Shops and Locker Networks Market Insight Report 2019; Apex Insight Ltd.: London, UK, 2019.

13. European Commission. Green Paper. An Integrated Parcel Delivery Market for The Growth of e-Commerce in the EU; European Commission: Brussels, Belgium, 2012.

14. Perboli, G.; Rosano, M.; Saint-Guillain, M.; Rizzo, P. Simulation-optimization framework for City Logistics: An application on multimodal last-mile delivery. IET Intell. Transp. Syst. 2018, 12, 262-269. [CrossRef]

15. Iwan, S.; Kijewska, K.; Lemke, J. Analysis of Parcel Lockers' Efficiency as the Last Mile Delivery Solution-The Results of the Research in Poland. Transp. Res. Procedia 2016. [CrossRef]

16. Gemius. E-commerce w Polsce 2020; Gemius and Izba Gospodarki Elektronicznej: Warszawa, Poland, 2020.

17. PRNewswire. Koloni Launches Smart Locker to Enable Contactless Delivery during COVID-19 Pandemic. Available online: https:/ / www.prnewswire.com/news-releases/koloni-launches-smart-locker-to-enable-contactless-delivery-during-covid19-pandemic-301054335.html (accessed on 30 June 2021).

18. Lemke, J.; Iwan, S.; Korczak, J. Usability of the Parcel Lockers from the Customer Perspective-The Research in Polish Cities. Transp. Res. Procedia 2016. [CrossRef]

19. Refaningati, T.; Nahry; Tangkudung, E.S.W.; Kusuma, A. Analysis of characteristics and efficiency of smart locker system (Case study: Jabodetabek). Evergreen 2020. [CrossRef]

20. Lin, L.; Han, H.; Yan, W.; Nakayama, S.; Shu, X. Measuring Spatial Accessibility to Pick-Up Service Considering Differentiated Supply and Demand: A Case in Hangzhou, China. Sustainability 2019, 11, 3448. [CrossRef]

21. Gatta, V.; Marcucci, E.; Nigro, M.; Serafini, S. Sustainable urban freight transport adopting public transport-based crowdshipping for B2C deliveries. Eur. Transp. Res. Rev. 2019. [CrossRef]

22. Enthoven, D.L.J.U.; Jargalsaikhan, B.; Roodbergen, K.J.; uit het Broek, M.A.J.; Schrotenboer, A.H. The two-echelon vehicle routing problem with covering options: City logistics with cargo bikes and parcel lockers. Comput. Oper. Res. 2020. [CrossRef]

23. Senge, P.M. The fifth discipline, the art and practice of the learning organization. Perform. Instr. 1991. [CrossRef]

24. Muñiz, I.; Dominguez, A. The Impact of Urban Form and Spatial Structure on per Capita Carbon Footprint in U.S. Larger Metropolitan Areas. Sustainability 2020, 12, 389. [CrossRef] 
25. Muñiz, I.; Rojas, C. Urban form and spatial structure as determinants of per capita greenhouse gas emissions considering possible endogeneity and compensation behaviors. Environ. Impact Assess. Rev. 2019, 76, 79-87. [CrossRef]

26. Sadik-Khan, J.; Solomonow, S. Streetfight: Handbook for an Urban Revolution; Books, P., Ed.; Penguin Books: New York, NY, USA, 2017.

27. Gehl, J. Cities for People; Island Press: Washington, DC, USA, 2010.

28. Montgomery, C. Happy City: Transforming Our Lives through Urban Design; Farrar, Straus and Giroux: New York, NY, USA, 2013.

29. McCann, B. Completing Our Streets: The Transition to Safe and Inclusive Transportation Networks; Island Press: Washington, DC, USA, 2013; ISBN 9781610914321.

30. Gemius. E-commerce w Polsce 2019; Gemius and Izba Gospodarki Elektronicznej: Warszawa, Poland, 2019.

31. Szoltysek, J. Logistyka Miasta; PWE: Warszawa, Poland, 2016.

32. Moroz, M.; Polkowski, Z. The Last Mile Issue and Urban Logistics: Choosing Parcel Machines in the Context of the Ecological Attitudes of the Y Generation Consumers Purchasing Online. Transp. Res. Procedia 2016, 16, 378-393. [CrossRef]

33. De Oliveira, L.K.; De Oliveira, R.L.M.; De Sousa, L.T.M.; De Paula Caliari, I.; De Oliveira Leite Nascimento, C. Analysis of accessibility from collection and delivery points: Towards the sustainability of the e-commerce delivery. Urbe 2019. [CrossRef]

34. Lachapelle, U.; Burke, M.; Brotherton, A.; Leung, A. Parcel locker systems in a car dominant city: Location, characterisation and potential impacts on city planning and consumer travel access. J. Transp. Geogr. 2018, 71, 1-14. [CrossRef]

35. Schwerdfeger, S.; Boysen, N. Optimizing the changing locations of mobile parcel lockers in last-mile distribution. Eur. J. Oper. Res. 2020, 285, 1077-1094. [CrossRef]

36. Speck, J. Walkable City. How Downtown Can Save America, One Step at a Time; North Point Press: New York, NY, USA, 2013.

37. Junping, X.; Peng, W.; Joh, K.; Bo, B. Using Micro-Level Data to Evaluate Infrastructure of the Walking Environment Around Bus Rapid Transit Stations: A Case Study of Xiamen, China. China City Plan. Rev. 2016, 25, 18-25.

38. Perboli, G.; Brotcorne, L.; Bruni, M.E.; Rosano, M. A new model for Last-Mile Delivery and Satellite Depots management: The impact of the on-demand economy. Transp. Res. Part E Logist. Transp. Rev. 2021, 145, 102184. [CrossRef] 